\title{
Stem Cells to Improve the Wound Healing
}

\author{
Silvana Bellini Vidor* and Emerson Antonio Contesini \\ Postgraduate Program in Veterinary Sciences, Universidade Federal do Rio Grande do Sul, Brasil
}

Submission:May 01, 2018; Published: May 09, 2018

*Corresponding author: Silvana Bellini Vidor, Postgraduate Program in Veterinary Sciences, Universidade Federal do Rio Grande do Sul. Av. Bento Gonçalves, 9090 - Agronomia - 91540-000, Porto Alegre, RS- Brasil, Tel: +55.51.33088059; Email: silvana.b.vidor@gmail.com

\begin{abstract}
The cellular therapy using Mesenchymal Stem Cells, specially its two subtypes - Bone-marrow Mesenchymal Stem Cells and Adipose Derived Stem Cells - can benefit by virtue of the possibility of differentiating in specialized cells that secrete and suppress growing factors and cytokines necessary in the lesion niche. When attracted by the pro-inflammatory sinalization of the lesion, they act using the paracrine signaling, decreasing the inflammation, increasing the angiogenesis and the cell migration and proliferation. The development in the researches regarding the association of the application of MSCs, with reconstructive surgery practices, leads to effective future results that can bring more benefits to the clinic practice of this field. This paper has the objective of briefly reviewing the literature about the usage of MSCs and its subtypes, the ADSCs, to improve the skin cicatrization.

Keywords: Mesenchymal stem cells; Adipose derived stem cells; Bone-Marrow Mesenchymal Stem cells; Skin flaps; Skin grafts; Wound contraction; Paracrine signaling; Pro-inflammatory Interleukins; Anti-inflammatory Interleukins.

Abbreviations: MSC: Mesenchymal Stem Cells; HLA-DR: Human Leukocyte Antigen; ADSC - Adipose derived stem cells; BM-MSC: Bone-Marrow Mesenchymal Stem Cells; SDF1: Stromal Cell-Derived Factor; PDGF: Platelet-Derived Growth Factor; IL: interleukin; TNFa: Tumor Necrosis Factor- $\alpha$; IFN $\gamma$ : Interferon- $\gamma$; VEGF: Vascular Endothelial Growth Factor; BFGF: Basic Fibroblast Growth Factor; EGF: Epidermal Growth Factor; KGF: Keratinocyte Growth Factor; HGF: Hepatocyte Growth Factor; PDGF: Platelet-Derived Growth Factor; TGF- $\beta$ : Transforming Growth Factor- $\beta$; FGF: Fibroblast Growth Factor; $\alpha$-SMA: Alpha-smooth muscle actin's; IRI: Ischemia-Reperfusion Injury
\end{abstract}

\section{Introduction}

Mesenchymal stem cells (MSCs) were first described by Friedenstein et al. [1,2]. MSCs are heterogeneous cell populations, called multipotent adult cells or somatic stem cells [3,4], capable of differentiation in most cell types in order to maintain and repair the organism. They are resident in different organs and tissues such as adipose tissue [4,5], bone marrow, umbilical cord, amniotic membrane [2,4], kidneys, liver, spleen, lungs, pancreas, tendons, synovial membranes, placenta, amniotic fluid and dental pulp [4]. The International Society for Cellular Therapy proposed three minimal criteria for defining MSCs:

a) Plastic adherence;

b) Positive expression (greater than $95 \%$ of the cell population) for CD105, CD73 and CD90 markers and negative, (maximum 2\% of the population) for CD45, CD34, CD14, CD11b, CD79a, CD19 and Human leukocyte antigen (HLA-DR) surface molecules, and

c) Ability to differentiate into osteoblasts, adipocytes and chondroblasts under standard in vitro differentiating conditions $[2,6]$.

Later, others researchers complemented this characterization with new markers: CD13, CD44, CD54, 106 and Stro-1 [4] and the presentation of fibroblast cellular morphology $[3,4]$.
MSCs have a great potential to the tissue repairment and regeneration in reconstructive plastic surgery, preventing ischemic lesions in skin flaps [7-14] and in skin grafts $[15,16]$. MSCs are capable of reducing severe atrophy, retraction, fibrosis and ulceration skin signals, caused by radiotherapy $[17,18]$. Combined with the lipoinjection in face and body defects and in rejuvenating esthetic treatments, MSCs raise in 35\% the survival rate and the microvasculature from the injected fat [18]. Also, diabetic patients with ischemic wounds show greater survival rates and lower number of amputations in affected limbs, when treated with Adipose derived stem cells (ADSCs) [19]. The MSCs improved the skin healing at induced burns in rats [20,21]. In dermatology, the MSCs are being clinically used for inflammatory diseases [22-28], Graft-Versus-Host Disease [23,25], Chrown Disease [29], Systemic Sclerosis, Lupus or dermatomyositis $[24,28,30]$.

When compared with the usage of Growing Factors, that like any drug has a limited half-life, the cellular therapy using MSCs, specially in its two subtypes - the Bone-Marrow Mesenchymal Stem Cells (BM-MSCs) and ADSCs - can bring greater benefits because of: their expansion capacity in cellular culture; stable phenotypic expression; and possibility of differentiating in specialized cells, that secrete and suppress cytokines and growing 
factors in the injury [13,31-33]. However, long expansion periods of the cellular culture, to achieve effective therapeutic doses, raise the possibility of infection from the host. Because of that, the ADSCs still have to be heavily studied to the application in the clinic routine [2]. This way, this study has as objective briefly review the literature about the usage of MSCs and its subtypes, the ADSCs, to improve the skin healing.

\section{Discussion}

The MSCs are capable to answer and adjust their functions, when exposed to cells or typical factors of the lesion environment $[33,34]$. They have an attraction capacity to the inflammation areas [33-35] or tumors, because of the molecules CCL21 or HMGB1, known as homing. In case of lacking of this signalization, they are attracted in order of preference to the lungs, liver and spleen [35]. The MSCs show chemotaxis in vitro by the Stromal Cell-Derived Factor (SDF1), Platelet-Derived Growth Factor
(PDGF), Insulin-Like Growth Factor-1, Interleukin-8 (IL-8) and Tumor Necrosis Factor- $\alpha$ (TNF $\alpha)$. In murine models, the MSCs used in the systemic administration are capable of getting into the damaged tissues $[14,34,36]$.

The MSCs act, in many levels, in the three healing phases: inflammatory, proliferative and remodeling phase. Current studies indicate that the differentiation of the MSCs, that contributed to the tissue regeneration, is limited by the small survival rate of these cells in the damaged area. However, the paracrine signaling to the cells from the injury is the main mechanism of the MSCs, reducing the inflammation, stimulating the angiogenesis and inducing the cell migration and proliferation [33,37]. Nevertheless, other authors suggest that the differentiation of the MSCs in keratinocytes and endothelial cells have the same function as the paracrine signaling to accelerate the neovascularization and the reepithelialization of wounds [32] (Figure $1 \& 2$ ).

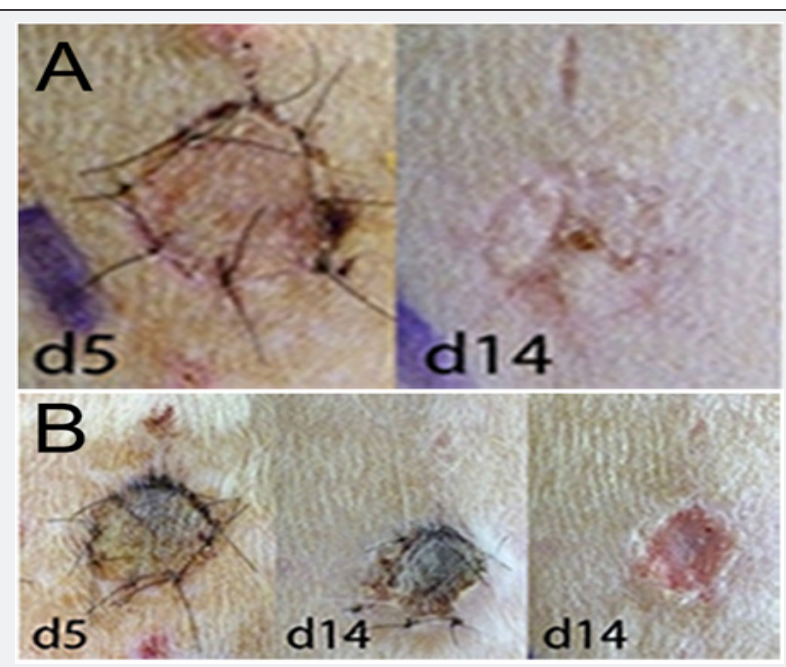

Figure 1: Full-thickness skin graft in rats:

(A) Graft that received the application of $1 \times 10^{6}$ ADSCs in their subcutaneous tissue: (d5) appearance five days after surgery and (d14) aspect 14 days after surgery;

(B) Graft that did not receive the application of ADSCs in its subcutaneous tissue: (d5) appearance with five postoperative days and (d14) aspect with 14 postoperative days, before removing the necrosis crust from the epidermis and after removing the crust.

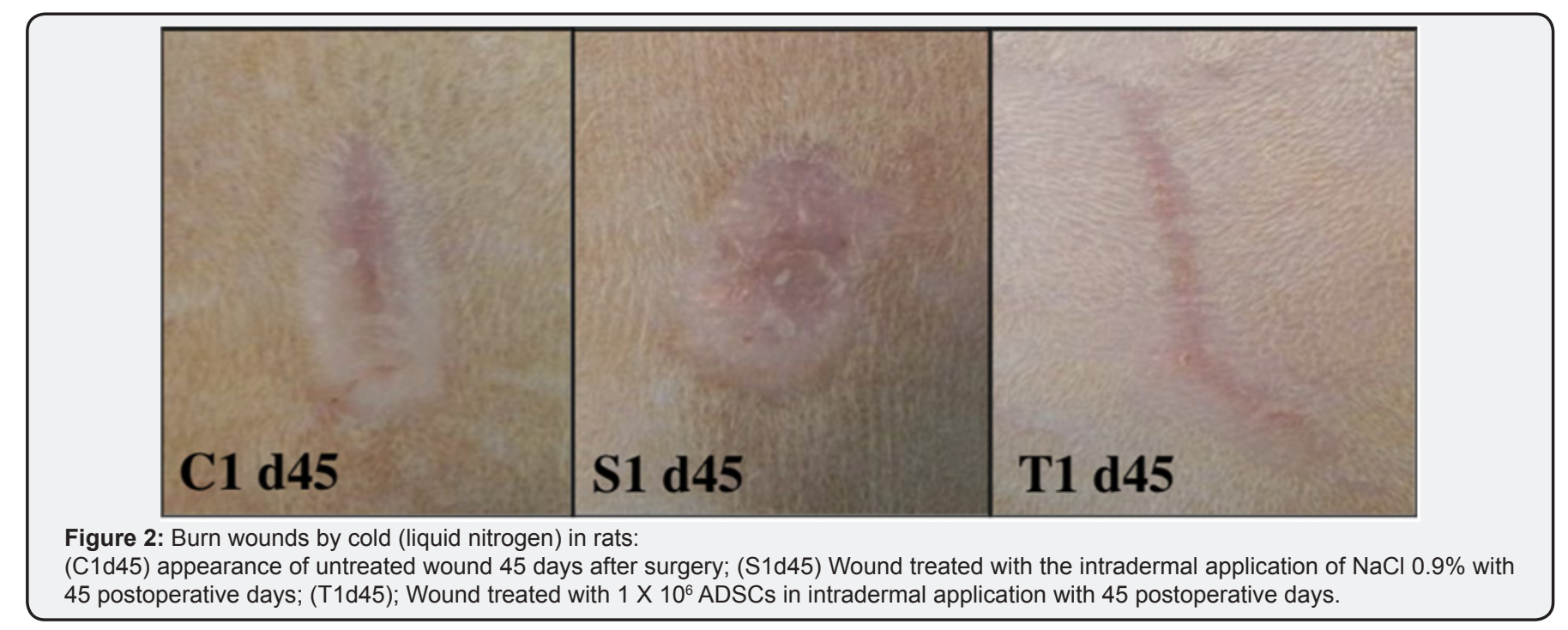


Some studies suggest that immunosuppressive potential is the same of both types of MSCs, ADSCs and BM-MSCs, in an inflammatory environment. Their local administration inhibited the $\mathrm{T}$ cells recruitment and proliferation [37-41] and decrease Interferon- $\gamma$ (IFN $\gamma$ ), Tumor Necrosis Factor- $\alpha$ (TNF $\alpha)$, IL- 6 and IL-1 $\beta$ expression in the skin grafts [39-41]. In the inflammatory phase (one to three days), the expression of anti-inflammatory cytokines IL-4 and IL-10 is increased while IL-2 proinflammatory cytokines, TNF- $\alpha$ and IFN- $\gamma$ are decreased, causing less local inflammatory reaction $[37,42]$. MSCs can also regulate macrophage activation and convert phenotype expression of M1 macrophages to M2 anti-inflammatory macrophages [39-41], which accelerates the wound healing. Additionally, MSCs act over the innate immunity to prevent the rejection of transplanted allografts, inhibiting the complement system activation [39]. The decrease of TFN- $\alpha$ also helps the reepithelialization after the proliferation phase [43]. The antimicrobial action from the MSCs are also important to limit the infection occurrence [37].

With the utilization of cell therapy in the proliferative phase (14 days) the production of important growth factors is increased: Vascular Endothelial Growth Factor (VEGF), Basic Fibroblast Growth Factor (bFGF) [32,37,42,43], Epidermal Growth Factor (EGF), Keratinocyte Growth Factor (KGF), Hepatocyte Growth Factor (HGF), Platelet-Derived Growth Factor (PDGF) and Transforming Growth Factor-beta (TGF- $\beta$ ). Through their paracrine action, the MSCs raise the migration and proliferation of keratinocytes, endothelial and epithelial cells. The fibroblasts proliferation is also enhanced, as well as the blood vessels' formation. This way, there is a better growing of a more vigorous granulation tissue [33,37,42,43]. The angiogenesis is a very important factor to the wound's healing, and the VEGF and the Fibroblast Growth Factor (FGF) are very important angiogenic factors [32].

Through the paracrine signaling, from the MSCs in the remodeling phase (21 days to one year), the fibroblasts produce collagen fibers in greater quantity and density, generating an increase in wound tensile strength $[37,42,43]$. At the same time, there is a smaller wound contraction and increased matrix-metalloproteinases production, that control the collagen deposition exacerbation, improving the aesthetic result and keeping the skin's function $[33,42,43]$. MSCs also contribute to the scar's appropriate remodeling with the increased secretion of VEGF and HGF, the adequate balance between TGF- $\beta 1$ and TGF- $\beta 3$ [37] and the increase of bFGF and TGF- $\beta$ which inhibit the Alpha-Smooth Muscle Actin ( $\alpha$-SMA) expression, responsible for myofibroblast phenotype [32].

Studies indicate that there is also the possibility of using BM-MSCs and ADSCs to protect the damaged tissues caused by the Ischemia-Reperfusion Injury (IRI) and to decrease the dysfunction of organs undergoing ischemia. The ADSCs are able to protect axial flaps from the IRI with results as satisfactory as the ones obtained in procedures without ischemia, because of the improvement in the angiogenic response and the blood perfusion elevation [10]. Many studies use the ADSCs to prevent ischemic injuries in skin flaps [7-14], as others [15,16] used them to improve the quality of skin grafts.

\section{Conclusion}

The MSCs - both BM-MSCs and ADSCs - are capable to answer and module their functions, when exposed to cells or typical factors of the lesion environment, attracted by the cell signaling to the inflammation areas. The researches developed till the moment point the paracrine signaling as the main mechanism from the MSCs, decreasing the inflammation, benefiting the angiogenesis and inducing the cell migration and proliferation in the damaged area. The progress on the researches about the association of MSCs with reconstructive surgery practices indicates good and productive results, which can benefit the clinical practice in this field.

\section{References}

1. Zago A, Covas T (2006) Células-tronco - A fronteira da medicina. (1st edn), Atheneu, São Paulo, Brasil, pp. 245.

2. Yang M, Sheng L, Zhang TR, Li Q (2013) Stem cell therapy for lower extremity diabetic ulcers: where do we stand? Biomed Res Int.

3. Gomillion CT, Burg, KJ (2006) Stem cells and adipose tissue engineering. Biomaterials 27(36): 6052-6063.

4. Gebler A, Zabel O, Seliger B (2012) The immunomodulatory capacity of mesenchymal stem cells. Trends Mol Med 18(2): 128-134.

5. Ginani F, Soares DM, Barboza CAG (2012) Influência de um protocolo de criopreservação no rendimento in vitro de células-tronco derivadas do tecido adiposo. Rev Bras Cir Plást 27(3): 359-363.

6. Dominici M, Le Blanc K, Mueller I, Slaper-Cortenbach I, Marini FC, et al. (2006) Minimal Criteria for defining multipotent mesenchymal stromal cells. The International Society for Cellular Therapy position statement. Cytotherapy 8(4): 315-317.

7. Ichioka S, Kudo S, Shibata M, Ando J, Sekiya N, et al. (2004) Bone Marrow Cell Implantation Improves Flap Viability after IschemiaReperfusion Injury. Ann Plast Surg 52(4): 414-418.

8. Lu F, Mizuno H, Uysal CA, Ogawa R, Hyakusoku H, et al. (2008) Improved viability of random pattern skin flaps through the use of adipose derived stem cells. Plast Reconstr Surg 121(1): 50-58.

9. Reichenberger MA, Heimer S, Schaefer A, Lass U, Gebhard MM, et al. (2012) Adipose derived stem cells protect skin flaps against ischemiareperfusion injury. Stem Cell Rev 8(3): 854-862.

10. Simman R, Craft C, Mckinney CC (2005) Improved survival of ischemic random skin flaps through the use of bone marrow nonhematopoietic stem cells and angiogenic growth factors. Ann Plast Surg 54(5): 546552.

11. Suartz CV, Gaiba S, França JP, Aloise AC, Ferreira LM (2014) Adiposederived stem cells (ADSC) in the viability of random skin flap in rats. Acta Cir Bras 29 Suppl 2: 6-9.

12. Uysal CA, Mizuno H, Tobita M, Ogawa R, Hyakusoku H (2009) The effect of adipose-derived stem cells on ischemia-reperfusion injury: immunohistochemical and ultrastructural evaluation. Plast Reconstr Surg 124(3): 804-815.

13. Yu WY, Sun W, Yu DJ, Zhao TL, Wu LJ, et al. (2018) Adipose-derived stem cells improve neovascularization in ischemic flaps in diabetic mellitus through HIF-1 $\alpha$ /VEGF pathway. Eur Rev Med Pharmacol Sci 22(1): 1016. 
14. Tang YH, Thompson RW, Nathan CA, Alexander JS, Lian T (2018) Stem cells enhance reperfusion following ischemia: Validation using laser speckle imaging in predicting tissue repair. Laryngoscope p. 1-8.

15. Zografou A, Tsigris C, Papadopoulos O, Kavantzas N, Patsouris E, et al. (2011) Improvement of skin-graft survival after autologous transplantation of adipose-derived stem cells in rats. J Plast Reconstr Aesthet Surg 64(12): 1647-1656.

16. Vidor SB, Terraciano PB, Valente FS, Rolim VM, Kuhl CP, et al. (2018) Adipose-derived stem cells improve full-thickness skin grafts in a rat model. Res Vet Sci 118: 336-344.

17. Sterodimas A, Faria J, Nicaretta B, Pitanguy I (2010) Tissue engineering with adipose-derived stem cells (ADSCs): current and future applications. J Plast Reconstr Aesthet Surg 63(11): 1886-1892.

18. Richter GT, Bowen T, Boerma M, Fan CY, Hauer-Jensen M, et al. (2009) Impact of vascular endothelial growth factor on skin graft survival in irradiated rats. Arch Facial Plast Surg 11(2): 110-113.

19. Kim CH, Lee JH, Won JH, Cho MK (2011) Mesenchymal stem cells improve wound healing in vivo via early activation of matrix metalloproteinase-9 and vascular endothelial growth factor. J Korean Med Sci 26(6): 726-733.

20. Caliari-Oliveira C, Yaochite JNU, Ramalho LNZ, Palma PV, Carlos D, et al. (2016) Xenogeneic mesenchymal stromal cells improve wound healing and modulate the immune response in an extensive burn model. Cell Transplant 25(2): 201-215.

21. Hosni AH, Rashed LA, Mahfouz S, Elsayed Hussein R, Alkaffas M, et al. (2017) Can mesenchymal stem cells pretreated with platelet rich plasma modulate tissue remodeling in a rat burned skin? Biochem Cell Biol 95(5): 537-548.

22. Ringdén O, Uzunel M, Rasmusson I, Remberger M, Sundberg B, et al. Mesenchymal stem cells for treatment of therapy-resistant graftversushost disease. Transplantation 81(10): 1390-1397.

23. Le Blanc K, Frassoni F, Locatelli F, Roelofs H, Lewis I, et al. (2008) Mesenchymal stem cells for treatment of steroid-resistant, severe, acute graft-versus-host disease: a phase II study. Lancet 371(9624): 1579-1586.

24. Liang J, Zhang H, Hua B, Wang H, Lu L, et al. (2010) Allogenic mesenchymal stem cells transplantation in refractory systemic lupus erythematosus: a pilot clinical study. Ann Rheum Dis 69(8): 14231429.

25. Zhou H, Guo M, Bian C, Sun Z, Yang Z, et al. (2010) Efficacy of bone marrow-derived mesenchymal stem cells in the treatment of sclerodermatous chronic graft-versus-host disease: clinical report. Biol Blood Marrow Transplant 16(3): 403-412.

26. Prasad VK, Lucas KG, Kleiner GI, Talano JAM, Jacobsohn D, et al. (2011) Efficacy and safety of ex vivo cultured adult human mesenchymal stem cells (Prochymal ${ }^{\mathrm{TM}}$ ) in pediatric patients with severe refractory acute graft-versus-host disease in a compassionate use study. Biol Blood Marrow Transplant 17(4): 534-541.

27. Herrman R, Sturn M, Shaw K, Purtill D, Cooney J, et al. (2012) Mesenchymal stromal cell therapy for steroid-refractory acute and chronic graft versus host disease: a phase 1 study. Int J Hematol 95(2): 182-188.
28. Scuderi N, Ceccarelli S, Onesti MG, Fioramonti P, Guidi C, et al. (2013) Human adipose-derived stromal cells for cell-based therapies in the treatment of systemic sclerosis. CellTransplant 22(5): 779-795.

29. Garcia-Olmo D, Herreros D, Pascual I, Pascual PA, Del-Valle E, et al. (2009) Expanded adipose-derived stem cells for the treatment of complex perianal fistula: a phase II clinical trial. Dis Colon Rectum 52(1): 79-86.

30. Connick P, Kollapan M, Crawley C, Webber DJ, Patani R, et al. (2012) Autologous mesenchymal stem cells for the treatment of secondary progressive multiple sclerosis: an open-label phase $2 \mathrm{a}$ proof-ofconcept study. Lancet Neurol 11(2): 150-156.

31. Gurtner GC, Werner S, Barrandon Y, Longaker MT (2008) Wound repair and regeneration. Nature 453(7193): 314-321.

32. Uysal CA, Tobita M, Hyakusoku H, Mizuno H (2014) The Effect of BoneMarrow-Derived Stem Cells and AdiposeDerived Stem Cells on Wound Contraction and Epithelization. Adv Wound Care (New Rochelle) 3(6): 405-413.

33. Prodinger CM, Reichelt TJ, Bauer JW, Laimer M (2017) Current and Future Perspectives of Stem Cells Therapy in Dermatology. Annals of Dermatol 26(6): 667-687.

34. Jackson WM, Nesti LJ, Tuan RS (2012) Mesenchymal stem cell therapy for attenuation of scar formation during wound healing. Stem Cell Res Ther 3(3): 20.

35. Khosrotehrani K (2013) Mesenchymal stem cell therapy in skin: why and what for? Exp Dermatol 22(5): 307-310.

36. Oh EJ, Lee HW, Kalimuthu S, Kim TJ, Kim HM, et al (2018) In vivo migration o mesenchymal stem cells to burn injury sites and their therapeutic effects in a living mouse model. J Control Release 279: 7988.

37. Maxson S, Lopez EA, Yoo D, Danilkovitch-Miagkova A, Leroux MA (2012) Concise review: role of mesenchymal stem cells in wound repair. Stem cells transl Med 1(2): 142-149.

38. Larocca RA, Moraes-Vieira PM, Bassi EJ, Semedo P, De Almeida DC, et al (2013) Adipose tissue-derived mesenchymal stem cells increase skin allograft survival and inhibit Th-17 immune response. PLoS One 8(10): e76396.

39. Le Blanc K, Davies, LC (2015) Mesenchymal stromal cells and the innate immune response. Immunol Lett 168(2):140-146.

40. Rasmusson I, Ringdén O, Sundberg B, Le Blanc K (2005) Mesenchymal stem cells inhibit lymphocyte proliferation by mitogens and alloantigens by different mechanisms. Exp Cell Res 305(1): 33-41.

41. Bartholomew A, Sturgeon C, Siatkas M, Ferrer K, McIntosh K, et al. (2002) Mesenchymal stem cells suppress lymphocyte proliferation in vitro and prolong skin graft suvival in vivo. Exp Hematol 30(1): 42-48.

42. Kim JW, Lee JH, Lyoo YS, Jung DI, Park HM (2013) The effects of topical mesenchymal stem cell transplantation in canine experimental cutaneous wounds. Vet Dermatol 24(2): 242-253.

43. Chen JS, Wong VW, Gurtner GC (2012) Therapeutic potential of bone marrowderived mesenchymal stem cells for cutaneous wound healing. Front in immunol 3: 192. 
This work is licensed under Creative Commons Attribution 4.0 License DOI: 10.19080/JHNSS.2018.03.555601

\section{Your next submission with Juniper Publishers will reach you the below assets}

- Quality Editorial service

- Swift Peer Review

- Reprints availability

- E-prints Service

- Manuscript Podcast for convenient understanding

- Global attainment for your research

- Manuscript accessibility in different formats ( Pdf, E-pub, Full Text, Audio)

- Unceasing customer service

Track the below URL for one-step submission https://juniperpublishers.com/online-submission.php 